\title{
Ontogenetic and seasonal shifts in the diet of the pemecou sea catfish Sciades herzbergii (Siluriformes: Ariidae), from a macrotidal mangrove creek in the Curuçá estuary, Northern Brazil
}

\author{
Tommaso Giarrizzo ${ }^{1,2} \&$ Ulrich Saint-Paul ${ }^{2}$ \\ 1. Laboratório de Biologia Pesqueira - Manejo dos Recursos Aquáticos, Universidade Federal do Pará (UFPA), Av. \\ Perimetral 2651, Terra Firme, 66040170 Belém, PA - Brazil; tgiarrizzo@yahoo.it \\ 2. Center for Tropical Marine Ecology (ZMT), Fahrenheitstr. 6, 28359 Bremen, Germany; \\ ulrich.saint-paul@zmt.uni-bremen.de
}

Received 11-IV-2007. Corrected 26-X-2007. Accepted 09-III-2007.

\begin{abstract}
The feeding ecology of pemecou sea catfish (Sciades herzbergii) was studied bimonthly from September 2003 to July 2004 in a macrotidal mangrove creek at Curuçá estuary, Brazil. Feeding activity and relative importance of prey groups were assessed in 528 and 226 specimens (6.2 to $36.0 \mathrm{~cm}$ total length), respectively, using stomach contents. A total of 1820 specimens were caught. The fish left the creek with an average of $2.2 \%$ of their body weight in prey. Feeding activity was lower in the dry season (September and November 2003) than in the rainy season (January to May 2004). The diet was dominated by Ocypodidae and Grapsidae. Feeding strategies of the pemecou sea catfish indicated a slight variation between the diets of adults and juveniles; however; the main factor leading to diversification in the diet were the seasons. Opportunistic feeding behavior was observed in the dry season, shifting to more specialized feeding in the wet season. This temporal diet shift may be explained by the environmental seasonal variations (e.g. transparency of the water, high water level) in the intertidal mangrove creek habitat. Rev. Biol. Trop. 56 (2): 861-873. Epub 2008 June 30.
\end{abstract}

Keywords: Sciades herzbergii, feeding strategy, Ariidae, mangrove, stomach contents, Ocypodidae, Grapsidae.

Ariids are medium to larger-sized demersal catfishes, mostly inhabiting estuarine and marine environments in tropical and sub-tropical regions (Acero and Betancur 2007), and are an important component of many tropical fisheries (Darracott 1977, Tobor 1978, Vasudevappa and James 1980, Conand et al. 1995). The pemecou sea catfish, Sciades herzbergii (Bloch 1794), is distributed along the Atlantic coast from the Caribbean coast of Colombia to Northeast Brazilian coast (Sergipe) (Oliveira 1976, Froese and Pauly 2007). The species inhabits the brackish turbid waters of estuaries (Le Bail et al. 2000). On the Northern coast of Brazil, S. herzbergii is an abundant species in the intertidal mangrove habitat (Barletta et al. 2003, Krumme et al. 2004, Giarrizzo and
Krumme 2007a) and is an important resource both for the subsistence and the economy of the local population. Usually the artisanal fishermen capture the pemecou sea catfish in first order intertidal mangrove creeks using non-selective fishing methods such as block nets (mesh size $3 \mathrm{~cm}$ ) or fish trappings, thereby causing an adverse effect on fish recruitment (Giarrizzo and Krumme 2007b).

Although pemecou sea catfish is an important fishery resource along the Brazilian coast, information on its biology and ecology is still lacking. The purpose of the present study is to describe the feeding ecology of pemecou sea catfish, by examining the ontogenetic and seasonal shift in diet in a macrotidal mangrove creek in the Curuçá estuary. 


\section{MATERIALS AND METHODS}

Study area: The present study was carried out in a mangrove tidal creek in the Curuçá estuary, approximately $160 \mathrm{~km}$ northeast of Belém, Pará, Northern Brazil $\left(0^{\circ} 10^{\prime} \mathrm{S}, 47^{\circ} 50^{\circ}\right.$ $\mathrm{W})$. This estuary has been designated as a conservation unit and is relatively undisturbed. The area is characterized by well-developed mangrove forests dominated by Rhizophora mangle (L.), Avicennia germinans (L.), and fewer Laguncularia racemosa (L.).

Average precipitation on the estuary is 2 $526 \mathrm{~mm}$ (ANA 2006; $\mathrm{n}=16$ years, range: 1 085-3 $647 \mathrm{~mm}$ ). Tides are semidiurnal and tidal amplitude in the estuary is about $4 \mathrm{~m}$. The whole mangrove swamp is inundated at high tide for only a few hours during spring tide. Samples were collected in a first order tidal creek located in the upper estuary at $1.2 \mathrm{~km}$ from Curuçá city. The perimeter, length and area of this creek is $777 \mathrm{~m}, 277 \mathrm{~m}$ and 20000 $\mathrm{m}^{2}$ respectively. The surface sediment of the inundated area is composed mostly of clay and silt, but there is also bedrock in the mouth of the creek.

Sampling: Samples were taken bimonthly between September 2003 and July 2004 from a tidal creek during the first quarter lunar phase, using a fyke net. This fishing gear is a passive sampler composed of two wings (20 m long, 6 $\mathrm{m}$ deep, with $20 \mathrm{~mm}$ stretch-mesh) and a hoopnet (with $13 \mathrm{~mm}$ stretch-mesh). The fyke net was set at the mouth of the creek at daytime slack high water (HW). In order to limit the regurgitation and digestion rates, during the tidal reflux (6 hours on average), every 15 minutes the fyke net was lifted to collect fish.

For each sampling event, salinity (salinity refractometer) and water transparency (Secchi disc) were recorded every 30 minutes in the mouth of the intertidal creek during ebb tide. The high water level was measured with a ruled stake placed in the thalweg of the creek downstream close to the net. The topography of the creek was surveyed (GPS, compass, tape measure) and a GIS map was generated.
The inundated area $\left(\mathrm{m}^{2}\right)$ for a medium neap tide event was quantified for the creek using ArcGIS. Thus, catch weights and abundance were standardized to biomass $\left(\mathrm{g} \mathrm{m}^{-2}\right)$ and density (ind. $\mathrm{m}^{-2}$ ), respectively.

Diet analysis: All specimens were measured to the nearest $0.1 \mathrm{~cm}$ total length (TL), and weighed to the nearest $0.01 \mathrm{~g}$ wet body weight (BW). The catalogue number of voucher specimens is MPEG12653 (Museu Paraense Emilio Goeldi, Belém, Pará, Brazil). At least 60 individuals were randomly taken from the total bimonthly catch to assess feeding activity. Subsequently, a minimum of 20 specimens with food in the stomach were picked for stomach content analysis. After dissection, the stomach contents of each fish were weighed to the nearest $0.01 \mathrm{~g}$ (stomach content fresh weight, FW). To measure which proportion of the fish weight was actual food consumed, the fullness index $(\% \mathrm{FI})$ was calculated following the formula defined by Hynes (1950):

$$
\% \mathrm{FI}=(\mathrm{FW} / \mathrm{BW}) \times 100
$$

The number of empty stomachs was counted and the vacuity index $(\% \mathrm{VI})$ was calculated: $\% \mathrm{VI}=($ Total of empty stomachs $/$ Total amount of stomachs analyzed) $\times 100$

As an indicator of energy storage, the Fulton's condition factor $(\mathrm{K})$ of each specimen $(n=528)$ was calculated from the relationship:

$$
\mathrm{K}=\left(\mathrm{EW} \times \mathrm{TL}^{-3}\right) \times 100
$$

where EW is the eviscerated wet body weight (g).

The assumption of isometric growth with the constant equal 3 (Bolger and Connolly 1989) was examined for the 528 specimens and no significant difference was detected with the allometric coefficient (b) of length-weight relationship $\left(\mathrm{b} \pm \mathrm{SE}=3.005 \pm 0.036, r^{2}=0.93\right.$, Student's t-test: $\mathrm{p}=0.44$ ).

Stomach contents were preserved in $70 \%$ ethanol solution and were examined under 
a binocular microscope. Prey found in the mouth cavity and the esophagus were excluded from the analysis because ingestion may have occurred in the net. Food items were identified to the lowest taxon possible using standard taxonomic keys (Melo 1996, 1999, Boltovskoy 1999). Number and wet weight of food items were registered to the nearest $0.0001 \mathrm{~g}$, after removal of surface water by blotting on absorbent paper. The contribution of each prey to the diet was assessed through three indices: (i) percentage frequency of occurrence $(\mathrm{F})$ represents the number of stomachs in which a food item was found, expressed as the percentage of total number of non-empty stomachs; (ii) percentage numerical abundance $(\mathrm{N})$ considers the number of individuals in each food category expressed as a percentage of the total individuals in all food categories; (iii) percentage gravimetric composition (W) represents the total wet weight of a food category expressed as a percentage of the overall weight of stomach contents. In order to synthesize these three indices, the Index of Relative Importance (IRI) of Pinkas et al. (1971), as modified by Hacunda (1981), was performed:

$$
\mathrm{IRI}=(\mathrm{N}+\mathrm{W}) \times \mathrm{F}
$$

The index was expressed as a percentage for each prey item:

$$
\% \text { IRI }=(\text { IRI } / \Sigma \text { IRI }) \times 100
$$

To assess for possible changes in diet with respect to size, fish were divided into two size-classes according to the gonad inspection: juveniles $(\mathrm{TL}<16 \mathrm{~cm})$ and adults $(\mathrm{TL} \geq$ $16 \mathrm{~cm})$. Feeding strategies between seasons (dry and wet) and size classes were analyzed following the graphical method of Costello (1990), modified by Amundsen et al. (1996). In this method, the prey-specific abundance $\left(\mathrm{P}_{\mathrm{i}}\right)$, defined as the average gravimetric contribution of a food item (only for pemecou sea catfish individuals that had this food item in their stomach), was plotted against the frequency of occurrence (F).
Statistical analysis: Bimonthly length frequency distributions were compared using a two-sample Kolmogorov-Smirnov test (KS). The bimonthly variation of $\%$ FI was tested by the non-parametric Kruskal-Wallis test (KW) followed by Dunn's (D) non-parametric procedure for a simultaneous post-hoc comparison (Sokal and Rohlf 1995). Pearson's productmoment-correlation analysis was performed with environmental parameters (salinity, water transparency and level at high water) and mean data of $\% \mathrm{FI}$ and $\mathrm{K}$. The data matrix of IRI values of family diet components for sample and size classes were square root transformed (Platell and Potter 2001) and the similarity was calculated using the Bray-Curtis similarity index (Marshall and Elliott 1997). A hierarchical agglomerative cluster analysis (using complete linkage) was performed to describe similarities in feeding habitats with regard to size classes and between months. The null hypothesis that there are no differences between seasons and size classes in diet composition was tested using non-parametric 'permutation' (two-way crossed analysis of similarities - ANOSIM) (Clarke and Green 1988). Multivariate analyses were performed using the statistical package PRIMER (Clarke and Warwick 1994).

\section{RESULTS}

Environmental parameters: There were notable seasonal patterns in average environmental conditions among the sampling months (Fig. 1). In the rainy season, from January to May, the salinity averaged $13.9(\mathrm{SD}=7.4)$, and in the dry season, from July to November, salinity increased to $27.2(\mathrm{SD}=3.1)$ (Fig. 1A). Depth at high water was lowest in the dry season (min: $3.1 \mathrm{~m}$ in November) and highest in the early wet season (max: $3.6 \mathrm{~m}$ in January) (Fig. 1B), due to the increasing runoff of precipitation. Mean water transparency was highest in the dry season (max: $0.8 \mathrm{~m}$ in November) and in the early wet season (January), and lowest in the wet season (min: $0.4 \mathrm{~m}$ in March) and early dry season (July) (Fig. 1C). 

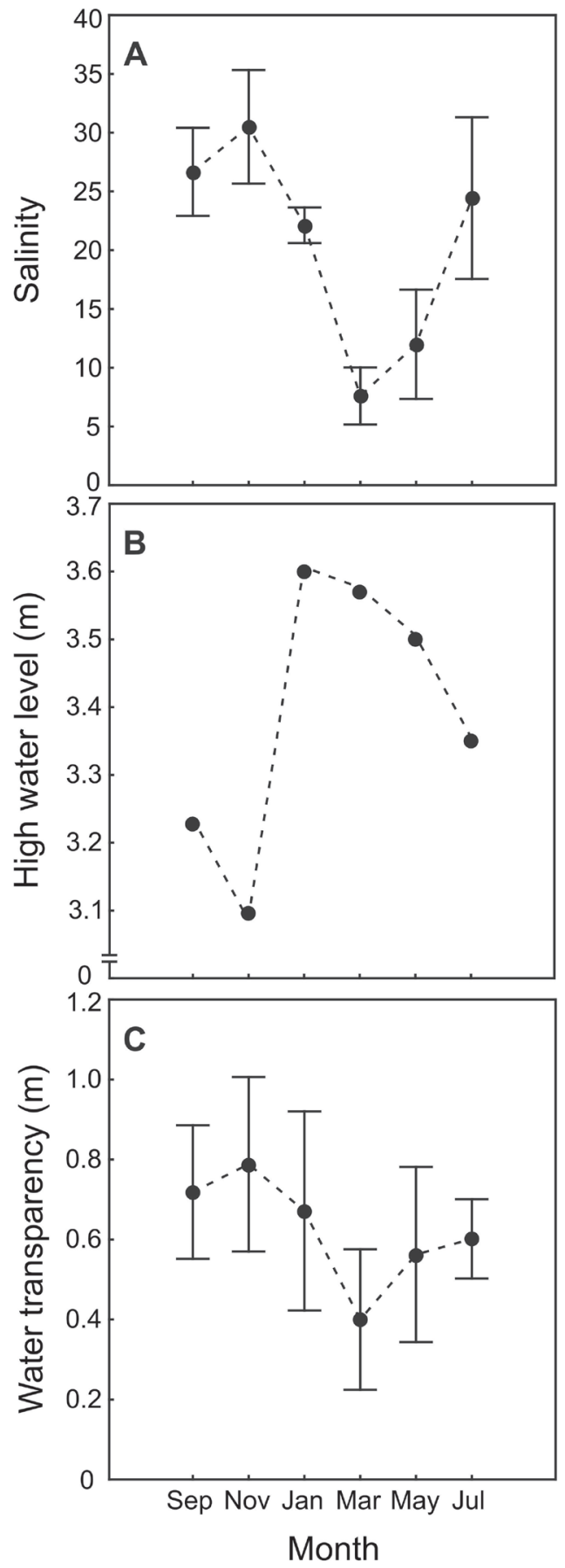

Fig. 1. Bimonthly variation of mean surface salinity (A), depth at high water (B) and mean water transparency (C) in a macrotidal mangrove creek in the Curuçá estuary (Northern Brazil) from September 2003 to July 2004. Vertical bars show $\pm 95 \%$ confidence interval.
Population: A total of 1820 specimens of $S$. herzbergii were captured. Mean fish density and biomass ( \pm SD) of $S$. herzbergii was 0.02 \pm 0.01 ind. $\mathrm{m}^{-2}$ (range: 0.01 to 0.03 ) and 0.48 $\pm 0.41 \mathrm{~g} \mathrm{~m}^{-2}$ (range: 0.01 to 1.01 ), respectively. The abundance was highest in the early dry season (July 2004; $\mathrm{N}=613$ ) and lowest in November $2003(\mathrm{~N}=162)$. Total lengths ranged from $2.7 \mathrm{~cm}$ to $36.0 \mathrm{~cm}$. Significant differences were found in the TL of individuals between different months (KS test, $\mathrm{p}<0.01)$ (Fig. 2). In September and March the recruitment of young occurred and, in the beginning of the rainy season (January), with low levels of salinity, larger post-spawning individuals ( $\mathrm{TL}$ mean $\pm \mathrm{SD}=$ $21.1 \pm 5.7 \mathrm{~cm}$ ) colonized the creek.

Feeding activity: Of the 528 stomachs examined, 72 (13.6\%) were empty. The vacuity index was higher in the dry season (September and November 2003) than in the rainy season (January to May 2004) (Fig. 3). The minimal quantity of ingested food occurred in November (mean $\% \mathrm{FI} \pm \mathrm{SD}=1.5 \% \pm 1.6$ ) and the maximum in March (mean \%FI $\pm \mathrm{SD}=3.2 \% \pm$ 2.2) (Fig. 3). The $\%$ FI follows an inverse trend to $\%$ VI. The specimens of $S$. herzbergii left the mangrove creek with an average of $2.2 \%(\mathrm{SD}=$ 2.4) of their body weight in prey. The fullness index was significantly different between the months (KW test, $\mathrm{p}<0.001$ ). The specimens collected in September and November showed \%FI values significantly lower than in the remaining months (Dunn test, $\mathrm{p}<0.05$ ). Furthermore, \%FI was significantly greater in March than in July (Dunn test, $\mathrm{p}<0.05$ ).

The bimonthly mean $\% \mathrm{FI}$ values were inversely correlated with water transparency $\left(r^{2}=0.89, \mathrm{p}<0.01\right)$, but independent from salinity and depth at high water $\left(r^{2}<0.64, \mathrm{p}>0.05\right)$.

The average Fulton's condition factor of $S$. herzbergii was $0.77(\mathrm{SD}=0.11)$. The bimonthly fluctuation in mean $\mathrm{K}$-values showed a clear seasonal pattern, with highest values in the wet season and lowest in the dry season (Fig. 4). No significant correlations were observed between the $\mathrm{K}$ and the environmental parameters recorded $\left(r^{2}<0.63, \mathrm{p}>0.05\right)$. 


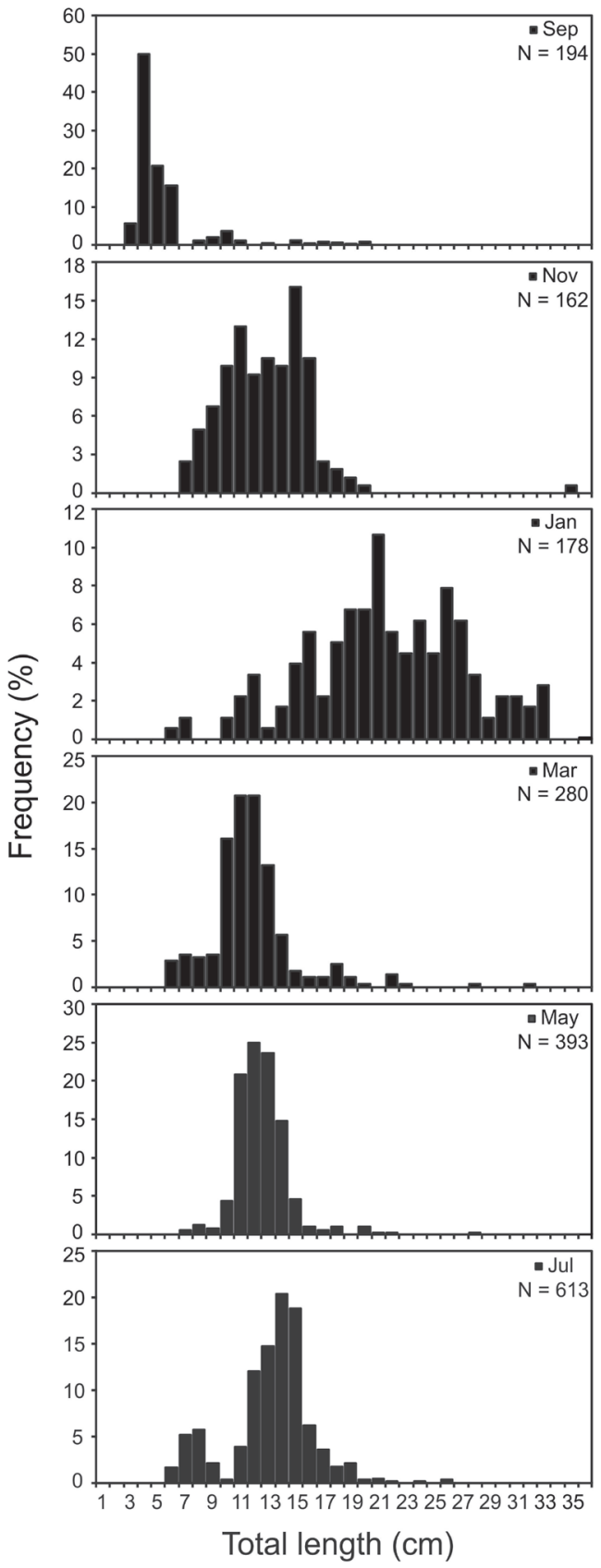

Fig. 2. Bimonthly variation in length frequency distribution of $S$. herzbergii $(\mathrm{N}=1820)$ caught in a macrotidal mangrove creek in the Curuça estuary (Northern Brazil) from September 2003 to July 2004.

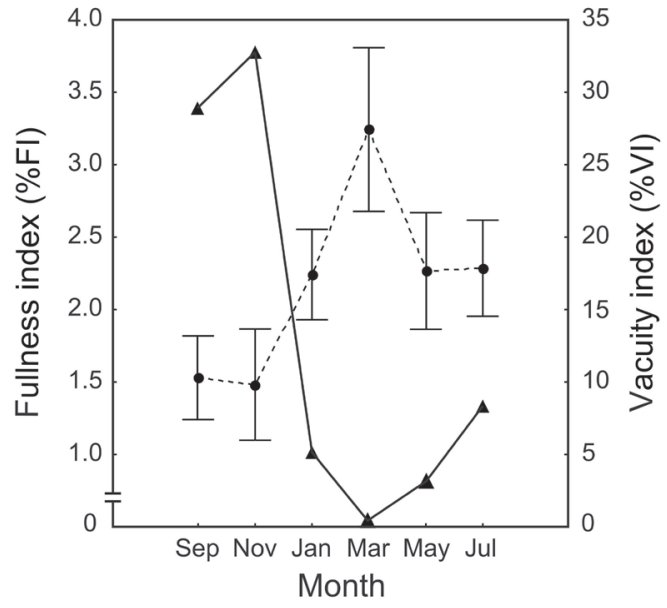

Fig. 3. Bimonthly variation in fullness index $(\% \mathrm{FI})(\bullet)$ and vacuity index $(\% \mathrm{VI})(\mathbf{\Delta})$ of $S$. herzbergii $(\mathrm{N}=528)$ caught in a macrotidal mangrove creek in the Curuçá estuary (Northern Brazil) from September 2003 to July 2004. Vertical bars show $\pm 95 \%$ confidence interval.

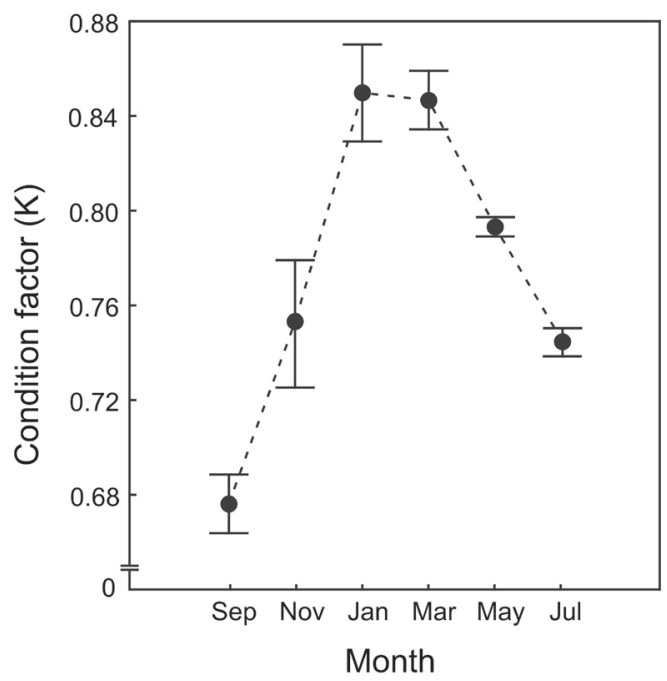

Fig. 4. Bimonthly variation of mean ( $\pm 95 \%$ confidence interval) Fulton condition factor (K) of 528 specimens of $S$. herzbergii caught in a macrotidal mangrove creek in the Curuçá estuary (Northern Brazil) from September 2003 to July 2004. 
Composition of the diet: The stomachs of the 226 pemecou sea catfish contained 1343 identifiable individual prey items. The mean number of prey per stomach was 5.9 ( $\mathrm{SD}=$ 11.4) and the mean prey weight per stomach was $0.69 \mathrm{~g}(\mathrm{SD}=1.35)$. In the stomach contents, a total of 41 diet components were observed, of which 27 were present in $5 \%$ of the stomachs. The diet of $S$. herzbergii consisted primarily of benthic crustaceans (mainly Ocypodidae and Grapsidae crabs and gammarid amphipods), polychaetes (mostly Capitellidae) and insects (mainly unidentified Insecta larvae) and secondarily of a variety of crabs (Porcellanidae, Portunidae and Goneplacidae), shrimps (Palaemonidae, Penaeidae and Alpheidae), mollusk (Mytilidae and Littorinidae), Teleostei and vegetal material.

Frequency, abundance, biomass and IRIvalues of different prey items found in the stomachs are shown in Table 1. The most frequent prey ingested were Ocypodidae (67.3\%), Grapsidae $(59.7 \%)$, Gammaridae (15.9\%), and insecta larvae (10.6\%). Ocypodidae and Grapsidae were the most abundant prey $(26.6 \%$ and $22.7 \%$ respectively) followed by Capitellidae $(19.7 \%)$ and Gammaridae (10.6\%). The major contributions in terms of biomass were attributed to the families Grapsidae (56.8\%) and Ocypodidae $(27.7 \%)$. According to the \%IRI, only two items represented more than $80 \%$ of the diet: Ocypodidae (44.2\%) and Grapsidae (39.7\%). The most important Ocypodidae and Grapsidae species were Uca cumulanta Crane 1943 (\%IRI= $27.4 \%)$ and Aratus pisonii Milne Edwards 1837 (\%IRI=9.4\%), respectively.

Ontogenetic and temporal shift in diet: The hierarchical agglomerative cluster analysis of IRI matrix differentiated, with a similarity of $65 \%$, four main groups (Fig. 5A): group 1 , adult specimens taken in the dry season

A

B

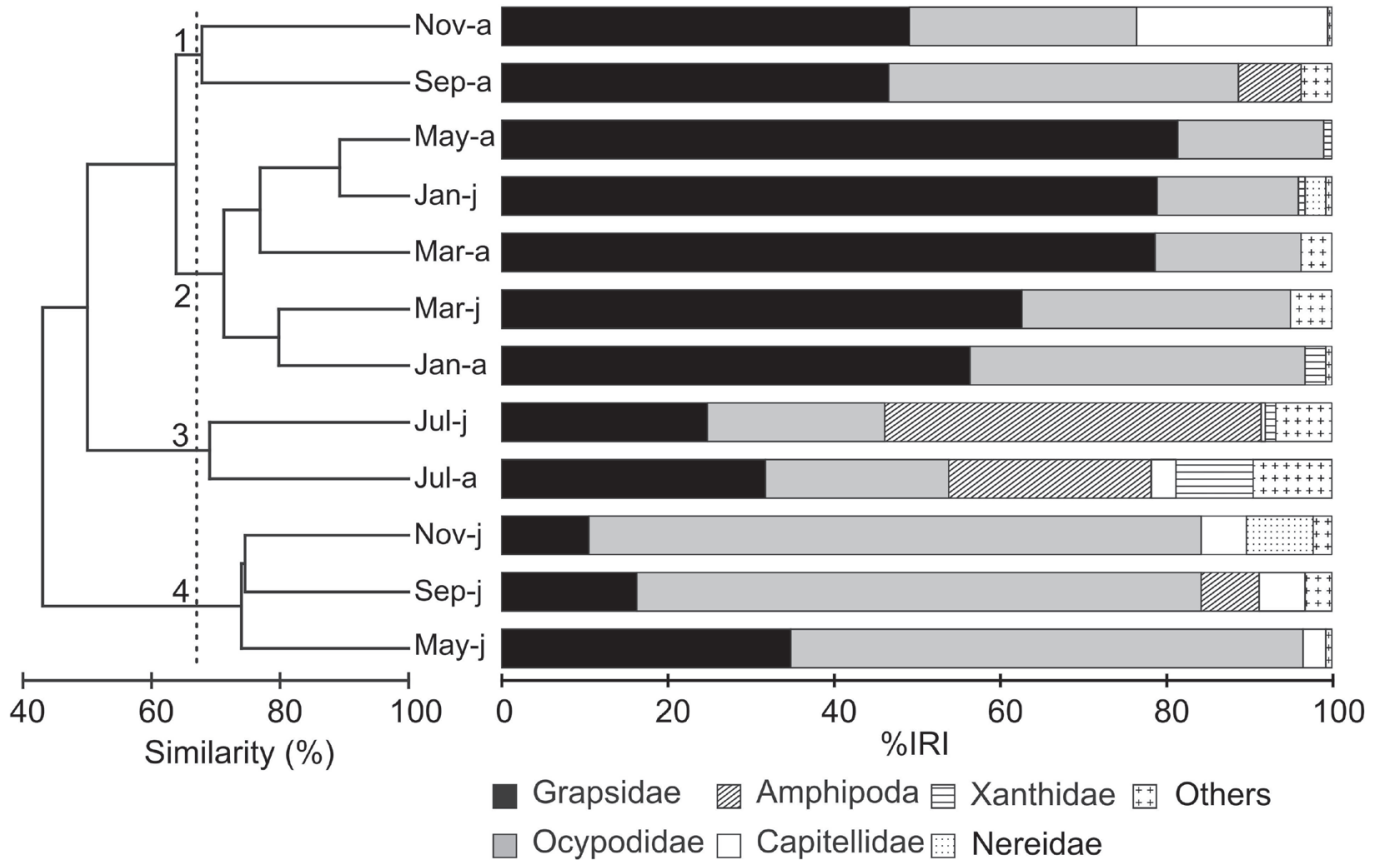

Fig. 5. (A) Dendrogram of cluster analysis of diet similarities among months and between small (j) and large (a) size classes of S. herzbergii collected between September 2003 and July 2004 in a macrotidal mangrove creek in the Curuçá estuary (Northern Brazil). (B.) Percent of the index of relative importance (\%IRI) of main prey items. 
TABLE 1

Frequency of occurrence $(F)$, numerical abundance $(N)$, gravimetric composition $(W)$ and Index of Relative Importance (IRI) of the stomach contents of 226 pemecou sea catfish collected in a macrotidal mangrove creek in the Curuçá estuary (Northern Brazil)

Item

ANNELIDA

Polychaeta [Pol]

Capitellidae n.i.

Nereididae n.i.

ARANAE [Ara]

CRUSTACEA

Amphipoda [Amp]

Gammaridae n.i.

15.93

Amphipoda n.i.

Copepoda [Cop]

Decapoda

Alpheidae [Alp]

Alpheus sp.

0.88

0.15

0.23

0.33

0.01

Goneplacidae [O.Bra]

Acidops cessacii

0.44

0.07

0.25

0.15

$<0.01$

Grapsidae [Gra]

Aratus pisonii

Sesarma rectum

Pachygrapsus gracilis

Metasesarma rubripes

Armases benedicti

Grapsidae n.i.

Ocypodidae [Ocy]

Uca cumulanta

Ucides cordatus

Uca vocator

Uca rapax

Uca maracoani

Uca mordax

Uca n.i.

Palaemonidae [Pal]

Macrobrachium n.i.

Penaeidae [Pen]
16.37

4.39

11.95

5.31

5.31

0.44

0.44

32.30

31.42

14.37

1.19

1.71

0.89

0.07

0.07

8.34

14.12

303.07

9.37

19.96

302.51

9.35

8.43

55.82

1.73

3.57

26.48

0.82

1.23

0.64

0.02

0.14

0.10

$<0.01$

9.26

594.79

18.38

5.75

0.44

0.44

0.44

30.53

2.21

0.45

1.71

4.78

0.15 
TABLE 1 (continuación)

Frequency of occurrence $(F)$, numerical abundance $(N)$, gravimetric composition $(W)$ and Index of Relative Importance (IRI) of the stomach contents of 226 pemecou sea catfish collected in a macrotidal mangrove creek in the Curuçá estuary (Northern Brazil)

Item

Farfantepenaeus subtilis

Penaeidae n.i

Porcellanidae [O.Bra]

Petrolisthes armatus

Portunidae [O.Bra]

Callinectes sp.

Callinectes sapidus

Squillidae [Squ]

$$
\text { Squilla sp. }
$$

Xanthidae [O.Bra]

Eurytium limosum

Isopoda [Iso]

Sphaeromidae n.i.

Isopoda n.i.

INSECTA [Ins]

Coleoptera n.i.

Himenoptera n.i.

Ortoptera n.i.

Unidentified larvae

MOLLUSCA [Mol]

Bivalvia

Mytelidae n.i.

Gastropoda

Littorinidae

\section{Littorina n.i.}

TELEOSTEI [Tel]

\section{Clupeiformes}

Engraulidae n.i.

Teleostei n.i

Vegetal material [Veg]

$\begin{array}{lllll}\mathrm{F}(\%) & \mathrm{N}(\%) & \mathrm{W}(\%) & \text { IRI } & \text { IRI\% } \\ 0.88 & 0.15 & 0.16 & 0.27 & 0.01 \\ 2.65 & 0.45 & 0.37 & 2.16 & 0.07\end{array}$

3.98

0.82

2.20

12.01

0.37

3.54

0.60

0.18

2.73

0.08

1.77

0.30

1.66

3.47

0.11

0.44

0.07

0.17

0.11

$<0.01$

7.96

1.71

5.96

61.09

1.89

0.37

0.05

0.94

0.03

2.21

0.97

0.23

2.64

0.08

2.21

0.45

0.48

2.06

0.06

3.10

0.52

0.06

1.81

0.06

0.44

0.07

0.19

0.12

0.00

10.62

2.61

1.17

40.12

1.24

0.88

0.15

$<0.01$

0.13

$<0.01$

Abbreviations for major categories of food items are shown in brackets.

$\begin{array}{ccccc}0.44 & 0.07 & 0.04 & 0.05 & <0.01 \\ 1.77 & 0.37 & 0.28 & 1.15 & 0.04 \\ 0.88 & 0.15 & 0.03 & 0.16 & <0.01\end{array}$


(September and November); group 2, specimens of both class sizes collected in the wet season (January, March and May); group 3, specimens of both class sizes collected in the early dry season (July); and group 4, juvenile specimens collected in the dry (September and November) and wet (May) seasons.

The most important prey taxa of group 1 were Grapsidae (mean \%IRI $\pm \mathrm{SE}=47.9 \% \pm$ 1.2), and Ocypodidae (34.6\% \pm 7.4) (Fig. 5B). A strong specialization was found in group 2 where Grapsidae accounted for $71.7 \% \pm 5.0$. However, a diet switch was observed in July (group 3) through an increase in prey diversity and dominance by amphipods $(34.8 \% \pm 10.6)$. The high contribution of Ocypodidae $(67.8 \% \pm$ $3.5)$ in the diet of juveniles differenced group 4 from all the other groups.
The two-way ANOSIM detected significant differences in the composition of diet between seasons (Global R-statistic value $=$ $0.67, p<0.05$ ), but not between size classes $($ Global R-statistic value $=0.09, \mathrm{p}>0.05)$.

Feeding strategy: The comparison of feeding strategies within the $S$. herzbergii population indicated a mixed feeding strategy, with varying degrees of specialization and generalization for different prey types (Fig. 6). The adult fish collected during the dry season showed a specialized feeding behavior dominated by Grapsidae $\left(\mathrm{P}_{\mathrm{i}}=91 \%, \mathrm{~F}=47 \%\right)$ and different Brachyuran crabs $\left(\mathrm{P}_{\mathrm{i}}=75 \%\right.$, $\mathrm{F}=32 \%$ ) (Fig. 6A). The high occurrence and lower average contribution to the stomach contents for Ocypodidae, showed a relatively high

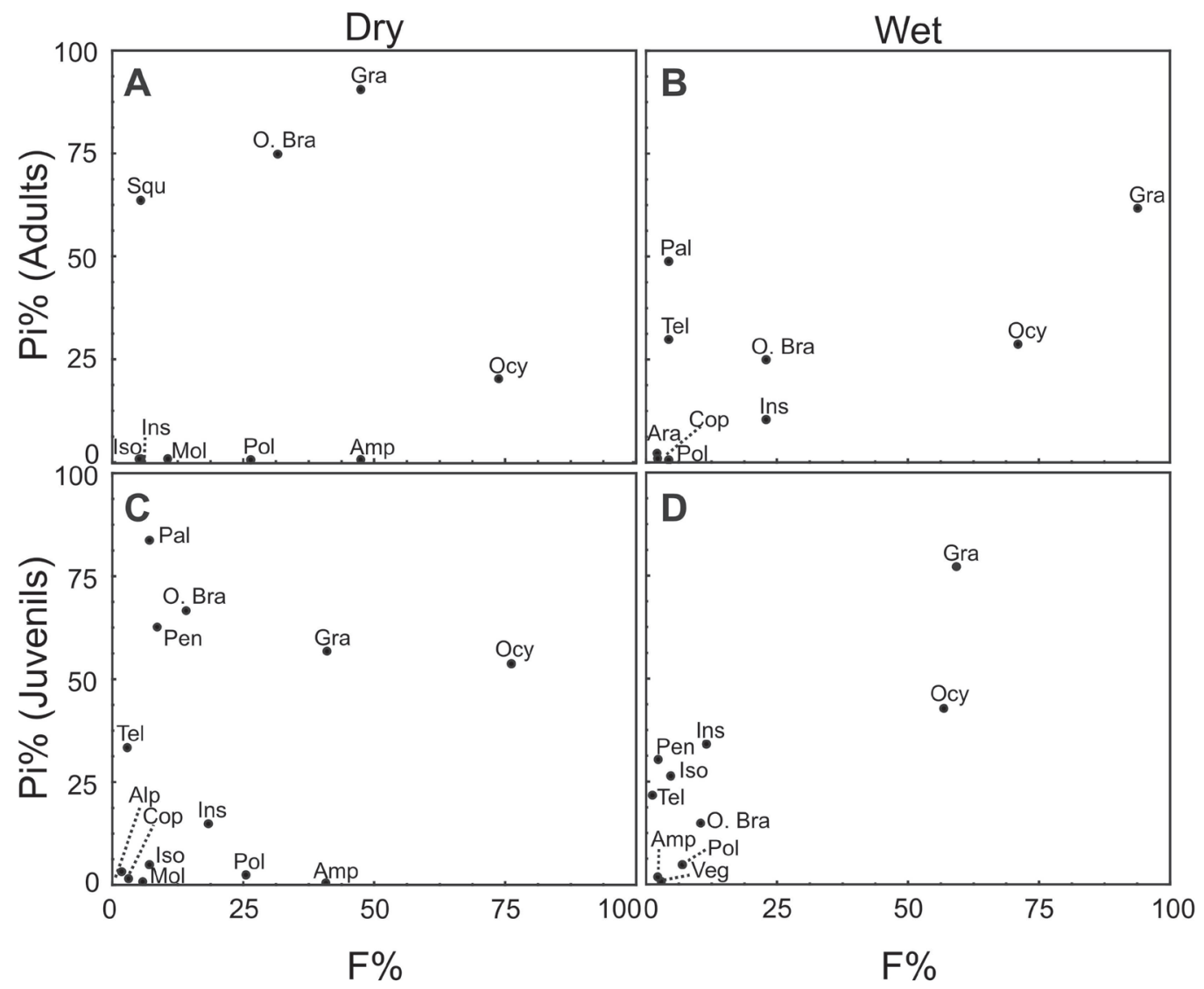

Fig. 6. Seasonal and ontogenetic variation of feeding strategy of S. herzbergii analysed by the graphic method of Amundsen et al. (1996). See Table 1 for abbreviations of major food categories. 
within-phenotype component, indicating a generalized feeding strategy. In the adults from the wet season, Grapsidae and Ocypodidae were the most frequent food item (Fig. 6B). They were ingested in $94 \%$ and $71 \%$ of stomachs, respectively, and accounted for $62 \%$ and $29 \%$ of the average contribution to the stomach weight, respectively. All other prey taxa constituted a small fraction of the weight of few stomachs $(\mathrm{F}<25 \%)$.

During the dry season, the juveniles had a wide range of feeding strategies. Palemonidae and Penaeidae shrimps and different Brachyuran crabs had a low frequency of occurrence and a high average contribution to the stomach weight, indicating a strong individual specialization (Fig. 6C). During this time, more than $40 \%$ of the analyzed fish fed mainly on Grapsidae and Ocypodidae crabs, showing a tendency for specialization. Low average contribution to the stomach weight for some prey taxa (Amphipoda, Polychaeta, Insecta) indicated a generalized feeding strategy. In the juveniles from the wet season, numerous rare prey taxa ingested in less than $15 \%$ of analyzed individuals indicated an opportunistic feeding behavior (Fig. 6D). However, the Ocypodidae and Grapsidae crabs found in $57 \%$ and $59 \%$ of stomachs, respectively, and accounted for $42 \%$ and $77 \%$ of the average contribution to the stomach weight, respectively, suggested different degrees of specialization.

\section{DISCUSSION}

Population characteristics: The high density of different size classes of pemecou sea catfish found in the area of this study suggest that intertidal mangrove creeks are breeding, nursery and feeding ground habitats for $S$. herzbergii. This is mainly attributable to: the high productivity of the system (Clough 1998, Dittmar and Lara 2001), accumulation of invertebrates (Robertson 1984, Laegdsgaard and Johnson 1995, Koch 1999), the lower risk of predation due to the structural heterogeneity of mangrove habitats (Thayer et al. 1987,
Laegdsgaard and Johnson 1995), and the high turbidity of water (Cyrus and Blaber 1987, Krumme et al. 2004). Juveniles of S. herzbergii are present in the intertidal mangrove creeks throughout the year with recruitment in September and March, emphasizing the existence of two reproduction cycles per year. Similar patterns have been found for the same species in French-Guyana (Le Bail et al. 2000) and Ceará (Chacon et al. 1994). In November, with the rapid increase in salinity (average 30.5 ), there is a reduction of population density attributed to migration toward the upper estuary where there is some input of marine waters (local informants pers. comm.).

Feeding activity: The fullness index with a high average value $(2.2 \%)$ suggests that feeding is a determining factor controlling $S$. herzbergii tidal migration into the mangrove. This is consistent with previous results for the same species from the Caeté estuary (Krumme et al. 2004).

Bimonthly variations in feeding activity show an increase in the fullness index during the wet season and a decrease in the dry season. Similar trends are observed in the temporal variation of Fulton's condition factor, indicating that the wet season provides better conditions for feeding and increasing energy reserves. Considering that total epifaunal crustacean production remains approximately constant between the seasons (Koch 1999), the oscillation of feeding activity can be explained by changes in environmental factors. The increase in the transparency of the water in the dry season is primarily responsible for improving the visibility of brachyuran crabs and optimizing their antipredator defenses, causing a decrease in the feeding activity of $S$. herzbergii. Another possible explanation is that prey are more available during the wet season when the tide is higher, increasing the inundation area accessible for intertidal fish. A similar pattern has been observed for other benthophage fish species in the same habitat; e.g. Centropomus pectinatus Poey 1860, Colomesus psittacus (Bloch and Schneider 1801); T. Giarrizzo unpubl. data, and 
for Periophthalmus sobrinus Eggert 1935 in a Kenyan mangrove (Colombini et al. 1996).

Diet and feeding strategy: Similarly to other Ariidae, pemecou sea catfish ingest prey whole, do not have a nipping feeding behavior, and feed mainly on crustaceans (Harris and Rose 1968). Krumme et al. (2004) reported that $S$. herzbergii is a mostly diurnal forager that preys on small brachyuran crabs and polychaetes. The mouth of $S$. herzbergii is subterminal, allowing it to select food consisting mainly of benthic invertebrates. The large contribution in number, biomass and IRI of brachyuran crabs suggests that $S$. herzbergii is an active benthic feeder that attacks its prey mainly in the soft bottom of the creek. This hypothesis is confirmed by characteristic marks observed at low tide in the mud of intertidal bank of creeks (pers. obs.) indicating predation of Ocypodidae crabs.

The dominance of Ocypodidae and Grapsidae crabs ingested by $S$. herzbergii presumably reflects the large number of these crustaceans within the intertidal region. According to Koch (1999) the Ocypodidae crabs represent more than $90 \%$ of biomass and abundance of epifaunal species in the intertidal mangrove habitat.

The ingestion of semi-terrestrial crabs [e.g. Uca vocator (Herbst 1804) and Uca rapax (Smith 1870)], restricted to elevated forest areas (Koch 1999), also suggests that feeding activity of $S$. herzbergii occurs with the high tide, when this habitat is more accessible. The high predation of $S$. herzbergii on tree-climbing crabs (e.g. A. pisonii) can be explained by the large numbers of these crabs in the $R$. mangle stilt roots during the hottest hours of the day, when slack high water occurs. The tree-climbing crabs frequently drop into the water to protect themselves from desiccation, thereby increasing the predation risk by $S$. herzbergii.

All methods of analysis of the dietary data of S. herzbergii [cluster analysis, ANOSIM, graphic method of Amundsen et al. (1996)] show pronounced seasonal shifts from generalist to specialist. For instance, in the wet season
S. herzbergii mainly consume brachyuran crabs. The high water turbidity favors this species hunting through the use of their sensorial barbells, particularly efficient to locate prey in muddy waters. The hierarchical agglomerative classification indicates a slight variation in the diet of adult and immature individuals. This feeding overlapping suggests that both these size classes share the abundant food resources (brachyuran crabs) without competition (Murie 1995).

Future research directions: Given the significant social - economic value of pemecou sea catfish for local people and when considering the spawning, nursery, and feeding functions of the intertidal mangrove creeks, caution should be taken in developing block net fisheries in this region. Inappropriate fishing practices could lead to local depletions of this fish.

The findings of this study are a fundamental step in developing multi-species assessment approaches, which are of urgent importance in the implementation of management strategies for the preservation of these natural habitats, and the promotion of sustainable fishing practices. Further research is needed on the investigation of the feeding activities of $S$. herzbergii under different environmental conditions [i.e. geographic location, time of day (day/night), tide (spring/neap tide) and tidal cycle (flood/ ebb tide)] while considering correlations to the availability of benthic invertebrates.

\section{ACKNOWLEDGEMENTS}

The authors thank A. Jesus, T. Catuxo, V. Coimbra, E. Lameira and B. Almeida for assistance in field collections and laboratory analyses. This work was funded by the Millennium Initiative Project Coastal Resources (www. mileniodomar.org.br) financed by the Ministry of Science and Technology of Brazil and the project MADAM (Mangrove Dynamics and Management) a cooperation between the Center for Tropical Marine Ecology (ZMT), Bremen, Germany, and the Universidade Federal do Pará 
(UFPA), Belém, Brazil. T. Giarrizzo acknowledges financial support by the $\mathrm{CNPq}$ grant 303958/2003-0.

\section{RESUMEN}

Estudiamos la ecología trófica del bagre guatero Sciades herzbergii, con periodicidad bimestral, desde septiembre de 2003 a julio de 2004, en un canal de marea del estuario del río Curuçá, norte de Brasil. Del total de 1820 ejemplares capturados, analizamos la actividad alimentaría y la importancia de las diferentes fuentes de alimento por evaluación de los contenidos estomacales de 528 y 226 ejemplares (longitud corporal 6,2 a $36,0 \mathrm{~cm}$ ), respectivamente. S. herzbergii sale del canal de marea con un valor promedio de 2,2 \% de su peso corporal como alimento. El ritmo alimentario fue menor durante el período seco (septiembre a noviembre de 2003) que en el lluvioso (enero a mayo de 2004). Los análisis de los contenidos estomacales de 226 ejemplares indicaron una dieta con predominio de Ocypodidae y Grapsidae. Las estrategias alimentarías de $S$. herzbergii mostraron pequeñas diferencias entre las dietas de los adultos y de los jóvenes, pero la variación estacional fue el factor que mejor definió la diversificación de la dieta. En el período seco hubo un comportamiento oportunista en la alimentación, cambiando a una dieta mas especializada durante el período lluvioso. Esta variación temporal en la dieta corresponde con la variación estacional en los hábitats del canal de marea.

Palabras clave: Sciades herzbergii, estrategia alimentaria, Ariidae, manglar, contenidos estomacales, Ocypodidae, Grapsidae.

\section{REFERENCES}

Acero, A.P. \& R.R. Betancur. 2007. Monophyly, affinities, and subfamilial clades of sea catfishes (Siluriformes: Ariidae). Ichthyol. Explor. Freshwaters 18: 133-143.

Amundsen, P.A., H.M. Gabler \& F.J. Staldvik. 1996. A new approach to graphical analysis of feeding strategy from stomach contents data modification of the Costello (1990) method. J. Fish Biol. 48: 607-614.

Barletta, M., A. Barletta-Bergan, U. Saint-Paul \& G. Hubold. 2003. Seasonal changes in density, biomass, and diversity of estuarine fishes in tidal mangrove creeks of the lower Caeté Estuary (northern Brazilian coast, east Amazon). Mar. Ecol. Prog. Ser. 256: 217-228

Bolger, T. \& P.L. Connolly. 1989. The selection of suitable indices for the measurement and analysis of fish condition. J. Fish Biol. 34: 171-182.
Boltovskoy, D. 1999. South Atlantic zooplankton. Backhuys, Leiden, The Netherlands.

Chacon, J.O., M.I.M. Alves \& M.S.C. de Mesquita. 1994. Alguns aspectos da reprodução do bagre branco, Selenapsis herzbergii (Bloch 1794), Pisces: Ostariophysi, Siluriformes, Ariidae. Bol. Tec. DNOCS 47: 43-78.

Clarke, K.R. \& R.H. Green. 1988. Statistical design and analysis for a "biological effects" study. Mar. Ecol. Prog. Ser. 46: 213-226.

Clarke, K.R. \& R.M. Warwick. 1994. Change in marine communities: an approach to statistical analysis and interpretation. Plymouth Marine Laboratory, Plymouth, United Kingdom.

Clough, B. 1998. Mangrove forest productivity and biomass accumulation in Hinchinbrook Channel, Australia. Mangr. Salt Marsh 3: 9-15.

Colombini, I., R. Berti, A. Nocita \& L. Chelazzi. 1996. Foraging strategy of the mudskipper Periophthalmus sobrinus Eggert in a Kenyan mangrove. J. Exp. Mar. Biol. Ecol. 197: 219-235.

Conand, F., S.B. Camara \& F. Domain. 1995. Age and growth of three species of Ariidae (Siluriformes) in coastal waters of Guinea. Bull. Mar. Sci. 56: 56-67.

Costello, M.J. 1990. Predator feeding strategy and prey importance: a new graphical analysis. J. Fish Biol. 36: 261-263.

Cyrus, D.P. \& S.J.M. Blaber. 1987. The influence of turbidity on juvenile marine fishes in estuaries. Part 1. Field studies at Lake St Lucia on the south eastern coast of Africa. J. Exp. Mar. Biol. Ecol. 109: 53-70.

Darracott, A. 1977. Availability, morphometrics, feeding and breeding activity in a multi-species, demersal fish stock of the Western Indian Ocean. J. Fish Biol. 10: 1-16.

Dittmar, T. \& R.J. Lara. 2001. Driving forces behind nutrient and organic matter dynamics in a mangrove tidal creek in North Brazil. Estuar. Coast. Shelf Sci. 52: 249-259.

Giarrizzo, T \& U. Krumme. 2007a. Spatial differences and seasonal cyclicity in the intertidal fish fauna from four mangrove creeks in a salinity zone of the Curuçá estuary, North Brazil. Bull. Mar. Sci. 80: 739-754.

Giarrizzo, T \& U. Krumme. 2007b. Temporal patterns in recruitment of selected tropical teleosts to mangrove creeks: implication for the fisheries management in North Brazil. Braz. Arch. Biol. Technol. In press. 
Hacunda, J.S. 1981. Trophic relationships among demersal fishes in a coastal area of the Gulf of Mexico. Fish. Bull. 79: 411-429.

Harris, A.H. \& C.D. Rose. 1968. Shrimps predation by the sea catfish Galeichthys felis. Trans. Am. Fish. Soc. 97: 503-504.

Hynes, H.B.N. 1950. The food of freshwater sticklebacks (Gasterosteus aculeatus and Pygosteus pungitius) with a review of methods used in studies of the food of fishes. J. Anim. Ecol. 1: 36-58.

Koch, V. 1999. Epibenthic production and energy flow in the Caeté mangrove estuary, North Brazil. PhD thesis, University of Bremen, Bremen, Germany.

Krumme, U., U. Saint-Paul \& H. Rosenthal. 2004. Tidal and diel changes in the structure of a nekton assemblage in small intertidal creeks in northern Brazil. Aquat. Living Resour. 17: 215-229.

Laegdsgaard, P. \& C.R. Johnson. 1995. Mangrove habitats as nurseries: unique assemblages of juvenile fish in subtropical mangroves in eastern Australia. Mar. Ecol. Prog. Ser. 126: 67-81.

Le Bail, P.Y., P. Keith. \& P. Planquette. 2000. Atlas des poissons d'eau douce de Guyane (Tome 2, fascicule 2). MNHN/SPN, Paris, France.

Marshall, S. \& M. Elliott. 1997. A comparison of univariate and multivariate numerical and graphical techniques for determining inter- and intraspecific feeding relationships in estuarine fish. J. Fish Biol. 51: 526-545.

Melo, G.A.S. 1996. Manual de identificação dos brachyura (caranguejos e siris) do litoral brasileiro. Plêiade, São Paulo, SP, Brazil.

Melo, G.A.S. 1999. Manual de identificação dos crustacea decapoda do litoral brasileiro: Anomura, Thalassinidea, Palinuridea e Astacidea. Plêiade, São Paulo, SP, Brazil.

Murie, D.J. 1995. Comparative feeding ecology of two sympatric rockfish congeners, Sebastes caurinus (copper rockfish) and S. maliger (quillback rockfish). Mar. Biol. 124: 341-353.

Oliveira, A.M.E. 1976. Composição e distribuição da ictiofauna nas águas estuarinas do rio Jaguaribe (Ceara - Brazil). Arqu. Cienc. Mar. 16: 9-18.

Pinkas, L., M.S. Olipham \& I.L.K. Iversor. 1971. Food habits of albacore, bluefin tuna and bonito in Californian waters. Fish. Bull. 152: 1-105.

Platell, M.E. \& I.C. Potter. 2001. Partitioning of food resources amongst 18 abundant benthic carnivorous fish species in marine waters on the lower west coast of Australia. J. Exp. Mar. Biol. Ecol. 261: 31-54.

Robertson, A.I. 1984. Trophic interactions between the fish fauna and macrobenthos of an eelgrass community in Western Port, Victoria. Aquat. Bot. 18: 135-153.

Sokal, R.R. \& F.J. Rohlf. 1995. Biometry. Biometry, Freeman, New York, USA.

Thayer, G.W., D.R. Colby \& W.F. Hettler. 1987. Utilization of the red mangrove prop root habitat by fishes in south Florida. Mar. Ecol. Prog. Ser. 35: 25-38.

Tobor, J.G. 1978. The trawl fishery of the sea catfish in the Nigerian coastal waters and observations on the fecundity, food and feeding habits of one of the commercially important species, Arks gambiensis (Bowdich, 1825). Bull. Inst. Fondam. Afr. Noire Ser. A Sci. Nat. 40: 621-639.

Vasudevappa, C. \& P.S.B.R. James. 1980. Maturity and spawning of the marine catfish, Tachysuncs dussumieri (Valenciennes), along the South Kanara coast. Proc. Indian Natl. Sci. Acad., 46: 90-95.

\section{INTERNET REFERENCES}

ANA: Agência Nacional das Águas. 2006. World Wide Web Electronic Data (accessed: July 30, 2006, http:// www.ana.gov.br).

Froese, R. \& D. Pauly. 2007. FishBase (accessed: March 30, 2007, http://www.fishbase.org). 